\title{
Nieuws van het reanimatiefront
}

\author{
L. Abraham-Inpijn
}

Casus Vragen:

'Moet ik leren reanimeren of kan ik beter een automatische externe defibrillator (AED) aanschaffen?'

'Hoe vaak moet ik een reanimatiecursus volgen?'

'Waarom moeten we in de tandheelkunde eerst naar de ademhaling kijken, de problemen liggen daar zelden?'

'Kunt $\mathrm{u}$ een calamiteitencursus en een reanimatietraining in drie uur geven?'

'Wanneer komen de nieuwe reanimatierichtlijnen?'

Al deze vragen rond het centrale thema 'reanimatie'

werden voor een belangrijk deel beantwoord in de RAI op 20 maart jl., waar de Nederlandse Reanimatie Raad (NRR) de nieuwe reanimatierichtlijnen presenteerde gebaseerd op de Guidelines 2005 van de European Resuscitation Council (ERC).

\section{Verklaring}

De gepresenteerde procedures zijn ontstaan onder auspiciën van de overkoepelende International Liaison Committee On Resuscitation (ILCOR); 280 experts hebben hieraan meegewerkt.

Men is uitgegaan van de literatuur die op kwaliteit is gescreend. Daarbij ontbraken om ethische redenen veelal de 'wetenschappelijk ideale' dubbelblinde, gerandomiseerde klinische studies.

De NRR heeft de internationale richtlijnen voor Basis Life Support (BLS) vertaald en heeft kleine aanpassingen doorgevoerd, nodig voor de Nederlandse situatie.

In grote lijnen zijn er twee belangrijke veranderingen:
- Meer borstcompressies per minuut. Deze wijziging is gebaseerd op het feit dat na een borstcompressie de perfusiedruk in de hersenen en de coronairvaten snel daalt tot 'nul'. De uitwisseling van zuurstof en nutriënten enerzijds en afvalproducten anderszijds is dan onmogelijk.

- Het versimpelen van de reanimatietechniek, waardoor meerdere handelingen in het beloop van de reanimatie zijn geschrapt. Deels geldt dit voor iedere hulpverlener, deels wordt er een verschil gemaakt tussen het reanimeren door leken en door professionals. Voor het weglaten van handelingen wordt geen andere onderbouwing gegeven dan dat het voor 'leken eenvoudig moet worden om te reanimeren'.

\section{Reanimatiesituatie}

Bij iedere bewusteloze patiënt dienen de volgende handelingen te worden uitgevoerd:

- Stel bewusteloosheid vast (roepen eigen naam of 'gaat alles goed met u?'; voorzichtig schudden). De patiënt die op geen van de bovengenoemde prikkels reageert, is diep bewusteloos en daarmee in levensgevaar. Er dient snel gehandeld te worden.

- Roep om hulp.

- Leg de patiënt plat neer, zonder kussen. Bij een accident in de tandartsstoel de stoel direct horizontaal zetten en alle apparatuur uit de mond halen. Er wordt niet meer gesproken over een harde onderlaag, maar de meeste tandartsstoelen zijn te zacht om adequaat te kunnen reanimeren. De patiënt zal dan toch op de grond moeten worden gelegd met de Handgreep van Rautek: 
2. Bij thoraxcompressies zijn de armen gestrekt in de ellebogen en staan de armen vanuit de schouders loodrecht op de patiënt.

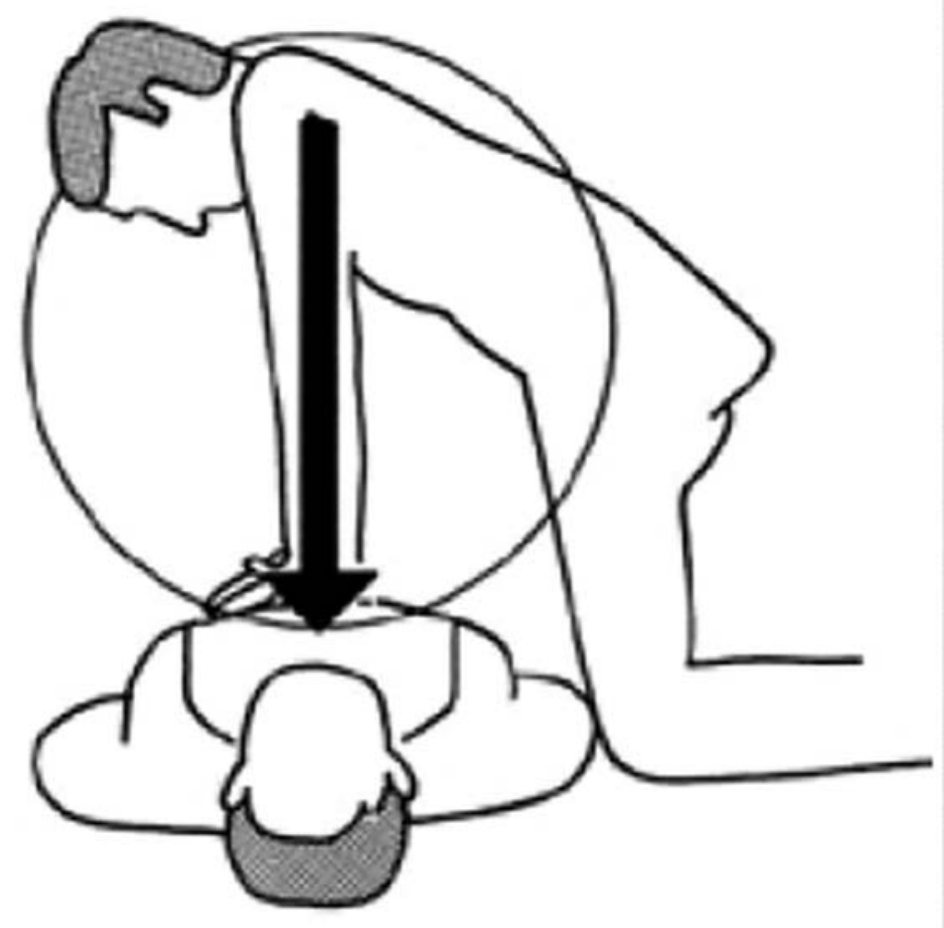

1. De head tilt chin lift-

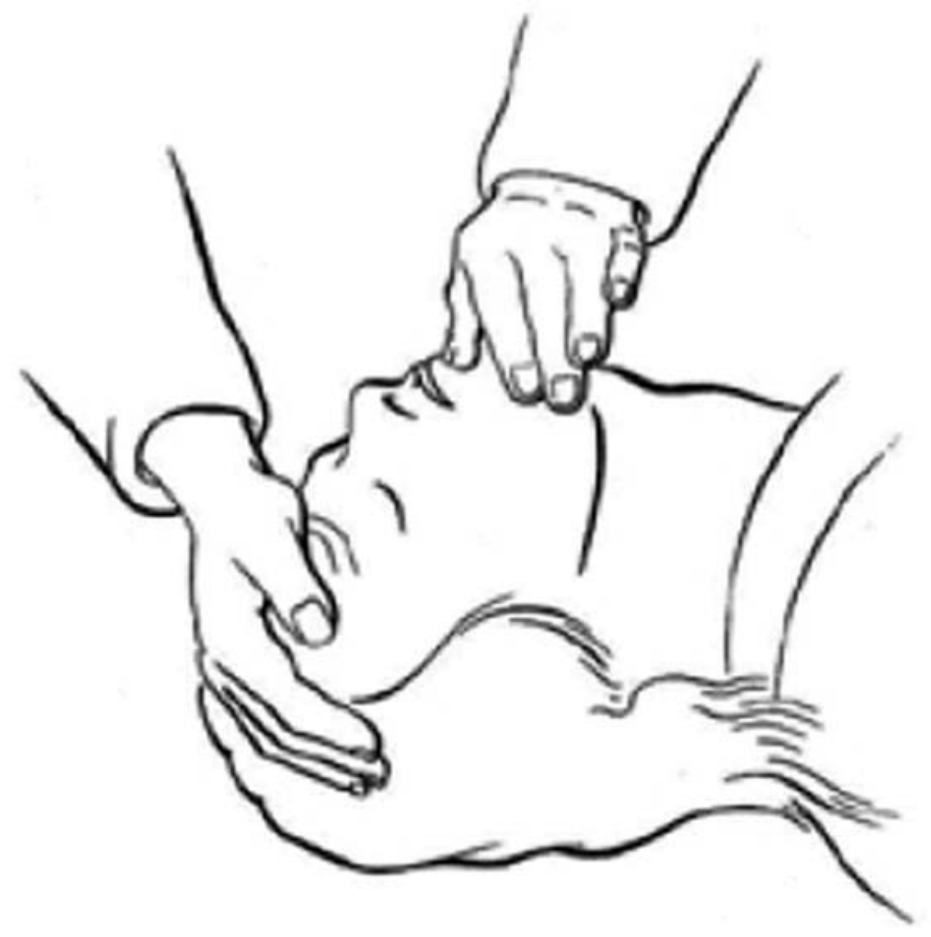
methode voor het vrijmaken van de luchtweg bij een bewusteloze patiënt. 
- Klap de armleuning neer of verwijder deze indien dat snel mogelijk is.

- Leg de armen van de patiënt over elkaar en leg de benen bij de enkels over elkaar.

- Ga achter het hoofd van de patiënt staan en grijp onder de oksels van de patiënt door naar voren en pak met beide handen (de rug van de hand boven) de bovenliggende onderarm van de patiënt (Handgreep van Rautek). Hierdoor worden de armen van de patiënt tegen zijn borst gefixeerd. Een andere hulpverlener neemt de over elkaar geslagen voeten van de patiënt op.

- Door de patiënt op te tillen en opzij te bewegen komt deze los van de stoel. Het rechterbeen van de tandarts wordt op dat moment snel naar voren geplaatst, zodat zijn bovenbeen het lichaam van de patiënt ondersteunt. De voeten van de patiënt worden voorzichtig op de grond gelegd. De patiënt glijdt als het waren langs het boven- en onderbeen van de tandarts op de grond. Houdt op het laatste moment het hoofd van de patiënt tegen, zodat dit niet op de grond komt. Realiseert $\mathrm{u}$ dat een bewusteloze patiënt veel en veel zwaarder is dan $u$ verwacht.

- Maak de luchtweg vrij door middel van de head tilt chin liftmethode.Plaats daarvoor één hand op het voorhoofd van de patiënt en breng het hoofd iets in retroflexie. Plaats de andere hand onder de kin en beweeg deze naar ventraal. Deze handgreep is noodzakelijk omdat bij de bewusteloze patiënt in rugligging met een intacte ademhaling de luchtweg vrijwel altijd geobstrueerd is. Door de verslapte musculatuur zakt de tong in de hypofarynx en sluit op deze wijze de luchtweg grotendeels af. Bij iedere geblokkeerde luchtweg ontstaan in de luchtstroom turbulenties die een geluid geven bij de ademhaling. In het geval van een hoge obstructie door de tong ontstaat een inspiratoire stridor of snurken. Overmatige extensie of zijwaartse rotatie van het hoofd moeten worden vermeden. De vertebrale arteriën kunnen bij maximale retroflexie, zeker bij patiënten met een artrose van de cervicale wervelkolom, worden afgeknikt. Daarbij kan ook veneuze stuwing ontstaan. Dit draagt bij tot de vorming van hersenoedeem, waartoe het hersenweefsel op basis van zuurstoftekort al neigt. Het eerste reinigen van de mond is verlaten, alleen een niet meer in situ zittende prothese wordt nog verwijderd

- Luister naar de ademhaling door de wang tegen de mond van de patiënt te houden met de blikrichting naar de thorax van de patiënt. Dan wordt de ademhaling van de patiënt gehoord, gevoeld en gezien. Hiervoor wordt 10 seconden uitgetrokken als de ademhaling normaal is. Helaas wordt het begrip 'normale ademhaling' in de richtlijnen niet gedefinieerd. Bij een normale ademhaling wordt de patiënt in stabiele zijligging gelegd, waarna elke minuut de ademhaling gecontroleerd dient te worden.

- Bij een abnormale ademhaling of bij twijfel: vraag iemand 112 te bellen met de melding 'reanimatiesituatie!' Bent $\mathrm{u}$ alleen, dan is dit het enige moment dat $\mathrm{u}$ de patiënt alleen mag laten. De patiënt wordt dus niet eerst ontbloot. Alleen knellende kleding aan de hals losmaken. Alleen een dikke jas wordt opengemaakt of men doet iets uit als men aan de juiste lokatie van de handen op de borst twijfelt.

- Begin borstcompressies door naast het slachtoffer te knielen ter hoogte van de bovenarm. Plaats de hiel van één hand midden op het borstbeen. Plaats de hiel van de andere hand bovenop de eerste. Strengel de vingers ineen, armen gestrekt vanaf de schouder. Beide armen houdt men loodrecht op de patiënt. De bovenste hand brengt via de onderste hand de kracht uit de armen over op het sternum. Men mag met de vingers noch de ribben, noch het processus xiphoideus, noch de buik raken. Deze positie van de hand voorkomt het optreden van inwendige kneuzingen, vooral de leverruptuur. Met kracht moet het sternum 4-5 cm naar binnen worden gedrukt. Wijze van masseren: thorax snel indrukken en totaal laten terugkomen. Laat het borstbeen dus helemaal terugkomen na de compressie. Het contact met het borstbeen echter niet verliezen. Deze relaxatiefase is nodig om bloed uit de periferie aan te zuigen. Herhaal de handeling met een frequentie van 100 per minuut (iets minder dan 2 borstcompressies per seconde). Men is hiermee weer terug bij de oude CAB-techniek uit de tachtiger jaren. Gedurende de eerste minuten van een circulatiestilstand blijft het zuurstofgehalte in het bloed vrij hoog. Beademen is daarom op dat moment minder belangrijk dan het geven van compressies. Een bijkomend voordeel blijkt dat hulpverleners vaak aarzelen bij het starten van de mond-op-mondbeademing, wat onnodig tijdsverlies betekent.

- Na 30 borstcompressies de luchtweg weer vrijmaken met de head tilt chin lift-methode.

- Knijp de neus dicht met twee vingers van de hand die op het voorhoofd rust. Adem normaal in (dus niet maximaal zoals bij de oudere technieken), blaas de uitgeademde lucht zodanig in de patiënt dat de lippen van de hulpverlener die van de patiënt nauw omsluiten. De beademingstijd dient 1 seconde te bedragen per insufflatie. Tijdens het inblazen controleert men het rijzen van de thoraxwand. Neem na de insufflatie de mond snel weg en let op de spontane passieve uitademing (thoraxwand daalt). Haal tijdens deze fase reeds adem 
voor de tweede inblazing. De mond-op-neusbeademing komt niet meer aan de orde.

- Herhaal 30 borstcompressies.

- Ga door met het geven van borstcompressies en beademing in een verhouding 30:2.

- Stop alleen voor een controle als het slachtoffer normaal begint te ademen. Anders dit ritme nimmer onderbreken.

- Is een tweede hulpverlener aanwezig, dan ieder 2 minuten wisselen.

- Als een automatische externe defibrillator beschikbaar $i s$, geeft men steeds één shock, waarbij de BSL zo kort mogelijk wordt onderbroken - Het opblazen van de maag tijdens beademing waardoor het longvolume wordt beperkt door verplaatsing van het diafragma, komt niet meer aan de orde. Daarmee vervalt ook de procedure van het leegdrukken.

\section{Richtlijnen die veranderd zijn:}

- Er wordt niet meer gesproken over hartstilstand, maar over circulatiestilstand en men gaat daarvan uit als iemand bewusteloos is met een abnormale ademhaling.Alleen professionals voelen nog naar een carotispols.

- De handen worden midden op het borstbeen geplaatst:

- geen gezoek meer naar de juiste plaats.

- Per beademing 1 seconde en geen 2 seconden.

- Frequentie borstcompressies/insufflaties wordt 30:2.

- Begin met 30 borstcompressies.

- Bij aanwezigheid van meerdere hulpverleners is er steeds één in actie. Iedere 2 minuten vindt er aflossing plaats. Deze wijze van reanimeren is dermate vermoeiend dat tijdens de discussie op het congres werd aan-

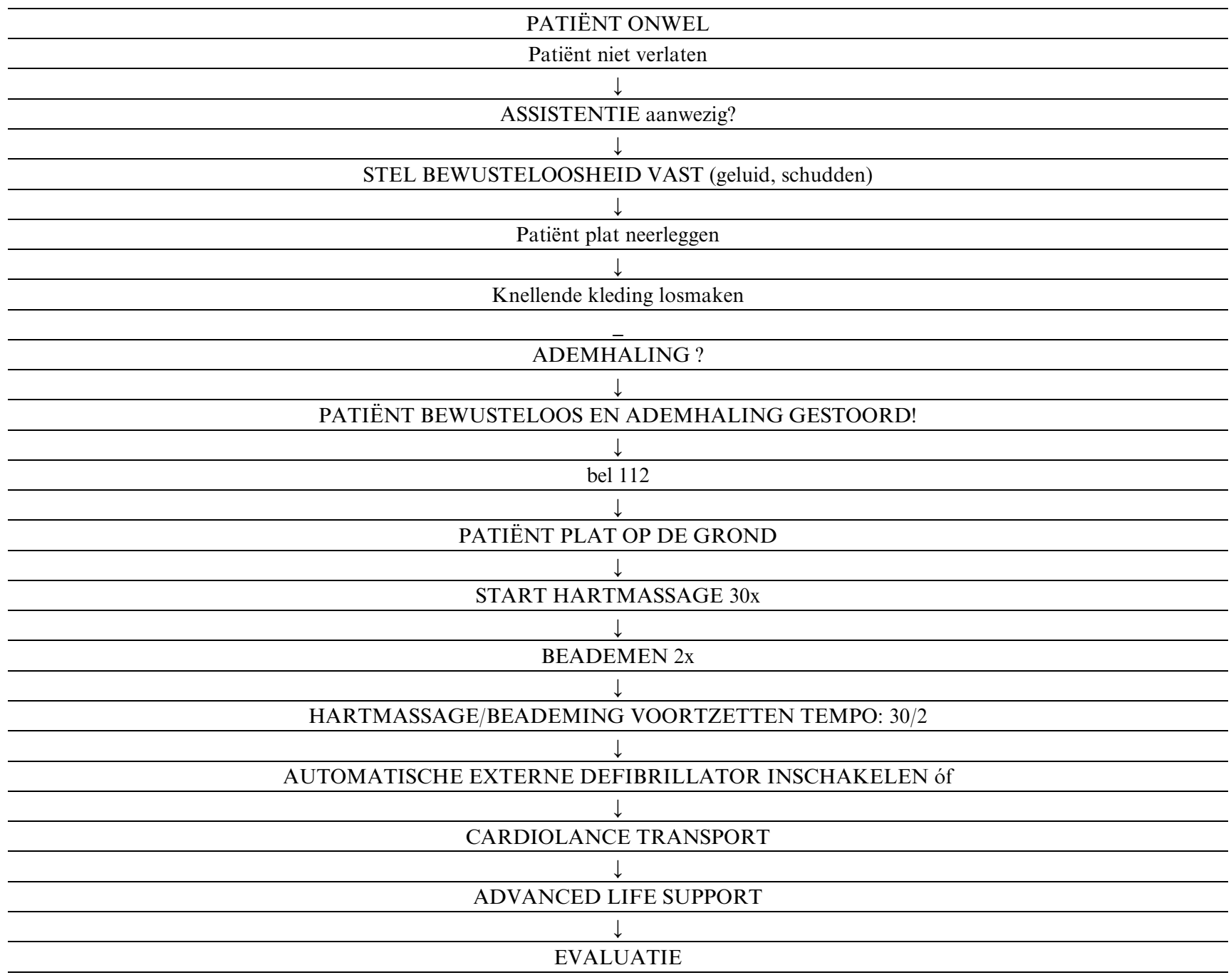


gegeven dat 60 +'ers, dit niet meer kunnen. Het antwoord van de organisatoren was duidelijk: 'Dan moet er meer getraind worden' en 'Dan moeten meer jonge leken worden opgeleid.'

- Hulpverleners zonder kinderreanimatie-opleiding kunnen de reanimatiemethode voor volwassene ook op kinderen boven 1 jaar toepassen. Dat is beter dan niets doen.

- Als men weigert te beademen, kan men alleen de borstcompressies 100/min constant toepassen. Ook dan geldt 'beter iets dan niets'. De psychologische weerstand tegen mond-op-mondbeademing kan verminderd worden door de mond met een (zak)doek te bedekken. Hierdoor wordt het effect van de beademing niet verzwakt. Het blijkt overigens dat filters op beademingsmaskers met een éénrichtingsventiel de overdacht van bacteriën van het slachtoffer naar de hulpverlener voorkomen. Er zijn een paar incidenten bekend met een tuberculose- en een SARS-besmetting. De overdracht van het HIV-virus tijdens reanimatie is nimmer gerapporteerd.

- Controle van de circulatie vindt niet meer plaats.

- Het noteren van het tijdstip wordt niet meer genoemd.

- Precordiale vuistslag behoort nu tot de specialistische reanimatie als iemand getuige is van de hartstilstand, de patiënt aan de monitor ligt zonder dat defibrillatieapparatuur aanwezig is en de handeling binnen 10 seconden kan worden uitgevoerd. 